\title{
Political Theology and Gullibility in Zimbabwe: The Cases of Ralph Dodge (1956 - 1964) and Pius Ncube (1997 - 2007)
}

\section{Margaret Chinyadza}

\begin{abstract}
Using the historical analytical approach, the article studies two periods in the history of Zimbabwean politics through the political theological lenses. These are the periods from Bishop Ralph Dodge's appointment as bishop of the United Methodist Church in the then Rhodesia in 1956 to his deportation in 1964, on the one hand, and from Bishop Pius Ncube's appointment as Bishop of the Catholic Church in 1997 to the time of his resignation in 2007, on the other hand. From a political perspective, the two periods may be demarcated as the period leading to the Unilateral Declaration of Independence (UDI), on the one hand, and the period leading to the crisis period of the years 20002008. By looking at these two periods, one in the colonial era and the other in independent Zimbabwe, this paper probes the question whether the practice of political theology brings defiance by religious actors of gullibility to bad governance in a given state. The article uses the cases of Bishop Ralph Dodge and Archbishop Pius Ncube to unpack the role of political theology in terms of refraining from political gullibility with respect to bad governance in Zimbabwe. The two men stood out and spoke up for the oppressed, refusing to be gullible to the policies of their respective governments.
\end{abstract}

Keywords: political theology, political gullibility, bad governance

\section{Introduction}

The church has an important role of providing the moral foundation and being the conscience of the nation (Okunoye 2012). Over the ages, religion 
and politics have developed into two inseparable twins, with God himself interested in the governance of his people from Old Testament times. It is God's will that there should be an organised state, which is shown by Jesus encouraging his disciples to play the dual role of giving to civil authority and to God their respective dues (Okunoye 2012). Christians as children of God should appreciate that God is interested in all aspects of human life - social, economic, political and spiritual (Okunoye 2012; Kaiso 2010). Luke 4:18 speaks to this effect.

The spirit of the Lord is on me, because he has anointed me to preach good news to the poor. He has sent me to proclaim freedom for the prisonersand recovery of sight for the blind, to release the oppressed, to proclaim the year of the Lord's favour (Holy Bible. New International Version).

It is from this perspective that one sees churches and religious practitioners play an active role in the governance of a nation, especially when there is a crisis. In the case of a crisis, religion always seeks to be relevant.

Whenever there is a crisis in a country, religion also undergoes a crisis when it responds to the crisis as propounded by Chitando (2013: $\mathrm{x}$ ). During a crisis, religious people, groups and communities always take a stand to try and find a way in which they can solve the crisis. The crisis that religion goes through is that there is support for the status quo and those who oppose it. This is mostly because; interpretation of the cause divides religious practitioners. Usually, different camps form because of supporting different groups (Chitando 2013: x). There are conservatives, radicals, and fence sitters, while the politicians capitalise on these divisions to advance their agenda. It is in light of this scenario that the article identifies two radical religious actors who operated during two crisis periods in the history of Zimbabwe. Ralph Dodge, also called The Revolutionary Bishop, was active during the period leading to the second Chimurenga, the period when Ian Smith and the Rhodesian government proposed the Unilateral Declaration of Independence (UDI). His was a voice among several missionaries that supported the African cause and the nationalists and it caused him to be deported. Pius Ncube, on the other hand, operated after independence during the crisis period of 2000-2008. He spoke vehemently against the abuses of the government and the Gukurahundi atrocities, straining the cordial relation- 
ship that had been there between the Catholic Church and the government and that of other church organisations that supported his prophetic voice. His voice was silenced when he was accused of infidelity. This article identifies the prophetic voice of these two individuals as political theology. It seeks to find out how effective the practice of political theology is in contributing to better governance in Zimbabwe.

The article begins by unpacking the meaning of the word 'gullibility', and then the term 'Prophetic political theology'. From there, the researcher provides a background to the religious situation in colonial Rhodesia from the 1960s onwards. From that period, the article brings to light the role played by Bishop Ralph Dodge whose Christianity was to a great extent more practical than theoretical against bad governance by the state and its consequences. He was a bishop during the times liberation theology was at its height in Latin America and Black Liberation theology was becoming prominent among the nationalists who were fighting for their liberation in Africa. His was a prophetic message in which he foresaw the rise of the black populace and pleaded with the white supremacists and the missionaries to train Africans in administrative duties in preparation for the time the Africans would take over from colonial rule. This was, however, met with hostility by the colonial government and he was deported. In refusing to accept the status quo, Dodge was rejecting gullibility to a system of bad governance. The article then moves on to post-colonial Zimbabwe during the crisis years of 2000-2008, which saw the rise of a prophetic voice in the form of Pius Ncube. He was very vocal against the atrocities done by the Zimbabwean government then and he was silenced when he was accused of infidelity. Again one raises the issue of gullibility. In refusing to support the status quo, he was rejecting gullibility to bad governance.

\section{Gullibility}

Greenspan defines gullibility as a failure of social intelligence in which a person is easily tricked or manipulated into an ill-advised course of action. The words 'gullible', and 'credulous' arfe commonly used as synonyms. Goepp and Kay (1984) state that while both words mean 'unduly trusting or confiding', gullibility stresses being duped or made a fool of, suggesting a lack of intelligence, whereas credulity stresses uncritically forming beliefs, suggesting a lack of scepticism. Jewell (2006) states the difference is a matter 


\section{Margaret Chinyadza}

of degree: the gullible are 'the easiest to deceive', while the credulous are 'a little too quick to believe something, but they usually aren't stupid enough to act on it'. Yamagishi, Kikuchi and Kosugi (1999) characterize a gullible person as one who is both credulous and naïve. Greenspan (2009) stresses the distinction that gullibility involves an action in addition to a belief, and there is a cause-effect relationship between the two states: 'gullible outcomes typically come about through the exploitation of a victim's credulity'. Some writers on gullibility focus on the relationship between the negative trait of gullibility and positive trait of trust. They are related, as gullibility requires an act of trust. Greenspan (2009) writes that exploiters of the gullible 'are people who understand the reluctance of others to appear untrusting and are willing to take advantage of that reluctance'. In 1980, Julian Rotter (in Greenspan 2009) wrote that the two are not equivalent: rather, gullibility is a foolish application of trust despite warning signs that another is untrustworthy.

In light of this article, both Dodge and Ncube refused to be gullible to the State apparatus in their different periods of operations. During colonial times very few clergy were bold enough to stand up and critique the government as Dodge did. The occasional criticism of government policies would come from church organisations and not from individuals. Pius Ncube spoke up against the government at a very dangerous time in the history of Zimbabwe when people were being silenced by the state. He refused to be naïve or to be taken in by the rhetoric of the government that accused the West for most of its challenges and refused to take responsibility and be accountable for their actions.

\section{Prophetic Political Theology}

Political theology was developed during the 1960s as a socio-critical theology by Jurgen Moltmann and Johann Baptist Metz (Schüssler Fiorenza 2013: 38; Van Wyk 2015: 1). Van Wyk points out that when this notion was brought up, there was concern among some that it would entail politicising the church. Both theologians, however, argue that there is no such thing as unpolitical theology (Van Wyk 2015: 1). A number of scholars support this, stating that politics and theology cannot be separated (Kee 1978; Moltmann 2013:2). To quote Moltmann (2013:2), 'There is consciously political theology and politically unconscious theology, but there is no such thing as an un-political theology ...'. It is Kee's conviction that, when individuals 
separate politics and theology, it basically points out to protecting selfinterests. What brings about political theology is not opportunism or an attempt to win a strategic advantage, but it is an understanding of the way we can be true to the fundamental character of Christian faith (Kee 1978: 3). Thus, one can safely say that, political theology is a critical theology with a commitment towards justice, peace and integrity of creation although there are many variations to its definition. In different contexts it can refer to Liberation Theology as well.

For the sake of this article, an analysis of the two types of Political Theology will be made, as propounded by the proponents of the theology. Political theology is distinguished between the old and the new. The old political theology entailed political sovereignty (Moltmann 2013: 3) and Statism (Metz 2013: 13). On the other hand, the new political theology is viewed as prophetic (liberation) theology (Moltmann 2013: 11), and a theology of justice (Metz 2013: 16-20). This article focuses on the new political theology. Metz (2013: 13) explains that classic (old) political theology understood politics in terms of national and legal policy and the legitimisation of an absolute and infallible state. It was generally a theology of political sovereignty (Schmitt 2012:275-276), meaning that the end justified the means irrespective of what the means might be. For Moltmann (2013: 4), new political theology is based largely on a theology of ethical and political anticipation. He also stresses that the hermeneutics of political theology is shaped by the context and community in which it is practised. His was a German setting.

Dodge and Ncube's political theology was shaped by the context of their day. Theirs was a Zimbabwean setting, though in different periods. Dodge was dealing with the oppressive nature of the colonial government, whereas Ncube was dealing with the oppressive nature of the post-colonial government. They were not silent to the injustices of their time. Like the prophets of the Old Testament, they spoke up against the oppression of the masses. They were a voice for the voiceless. Theirs was not just a theoretical theology but a practical one. Thus in practising Prophetic political theology both men were resisting gullibility to the status quo.

\section{Background of Religious Situation in Colonial Rhodesia}

The major aim of the missionary was therefore never to be a brother to the African - to help the African actua- 
lise himself but to ensure that the African would accept a servile and vassal role to the European. The biblical platitudes of brotherhood were nothing more than a ploy to destroy the African infrastructural basis of the society (Maboyi 2015).

This is the opinion of Ambassador Aaron Maboyi, and he is not alone. This has contributed to Christianity being viewed from a position of a sly, cunning religion that can take over the gullible at any time. The history of the country from colonial to post-colonial periods has seen a close relationship between the church and politics. Thomas (in Togarasei 2013: 97) contends that colonialism came riding on the back of religion, and the Bible has always been a political resource since its arrival in Zimbabwe, especially when it accompanied the Pioneer Column (Gunda \& Mtetwa 2013: 163).

The church was also quite instrumental in advancing the colonialist agenda. Joshua Nkomo observed that, the Christian religion sought life after death for the individual, while African religion sought rain, health and peace in the world of mankind (Nkomo 1984: 10). For him the African religion was more realistic and a person could easily identify with it. During the colonial era, the Bible was used to justify racial segregation and its deployment was to serve the political interests of the elite, while emphasising the theology of suffering to the masses (Daneel 1971: 208; Gunda \& Mtetwa 2013: 163). Although Sithole gives credit to the missionaries, he acknowledges that when missionaries came to Africa, they did not have intention to help African nationalism. Their sole aim was to propagate the gospel of Christ to their fellow human beings, and still some of them were more interested in the propagation of their own particular culture rather than the gospel of Christ (Sithole 1968: 84). Missionaries to and in Africa have been accused - and not without cause - of standing in the way of African nationalism. In spite of the above, Sithole still contends, and rightly so, that missionaries have been unwittingly helpful to the rise of African nationalism.

During the liberation struggle, the church was in the frontline. The church advocated the liberation of the oppressed, was active in promoting justice and human rights and identified with the suffering of the people. It also demanded accountability on the part of the colonial government (Muchena 2004: 256). In 1968, Sithole acknowledged that the enlightened political leadership of the day would have been next to impossible, but for the Christ- 
ian church that spread literacy to many parts of Africa (Sithole 1968: 94). The Christian church exercised its influence on the minds, attitudes and outlook of the African people who had direct contact with it. Many of the nationalists during the liberation struggle went through the hands of missionaries. Examples are Abel Muzorewa, Joshua Nkomo, Ndabaningi Sithole and Robert Mugabe (Sithole 1968: 89; Nkomo 1984: 10; Dodge 1986; Gunda \& Mtetwa 2013: 161).

Many developmental programmes were done by the church that contributed greatly to the later liberation of the African masses. Nkomo and Sithole state that the missionaries did more than spread the gospel, they actively promoted the building and maintenance of local primary schools teaching arithmetic, English, siNdebele, Religion and at secondary schools teaching among other subjects European as well African history (Nkomo 1984: 10; Sithole 1968: 91). The study of history placed very powerful weapons in the hands of many Africans and historical consciousness was one of the chief factors behind nationalism. Some missionaries were openly known for advancing the cause of the African majority. Bishop Dodge of the United Methodist Church had the tendency to appoint Africans to positions formerly meant just for whites. He was also expelled from Rhodesia when it was found out that he supported the black nationalists (Dodge 1986: 139).

\section{The Gullible Ones}

The following was the general sentiment of some missionaries at the Methodist Synod held in 1959 in Southern Rhodesia:

Colonisation was legitimate and had among other things been of benefit to African society. The African people on the other hand, had legitimate aspirations and ultimately would control the country. For the present however they were immature and unequipped educationally and technically to do so (Peaden 1979:194-195).

Some churches employed conservative approaches concerned with maintaining the peace of mind of their white members than in making a stand for justice. The Dutch Reformed Church, for example, officially adopted a neutral stance on all political matters. However, Daneel (in Peaden 1979: 196) contends that its silence has often been interpreted by its African 
members as support for government policies. In practice it actually encouraged segregation of the races in its congregations and so gave tacit support to Afrikaner political philosophy. It is in this church-state relations scenario that Bishop Ralph Dodge of the American Methodist Church came to the scene in Southern Rhodesia. The Methodist synod and the Dutch Reformed Church were in agreement with the Rhodesian government that Africans were not ready to govern themselves, which can be interpreted as being gullible to the status quo. Dodge on the other hand, as shall be discussed below, refused to accept the Rhodesian government and the sentiments of the other missionaries.

\section{A Missionary with a Difference: The Revolutionary Bishop}

For a time, the American missionaries of the United Methodist Church and other missions maintained that they were unqualified to speak on political matters because they were aliens (Peaden 1979: 196). However, in 1956, Ralph Dodge was appointed Bishop of the American Methodist Church diocese of Rhodesia, Angola, Mozambique and Transvaal. In defiance of the status quo and clear evidence of his not being gullible, Peaden (1979: 196) reports that in the 1960s, Dodge made preparations for the africanisation of the United Methodist Church by sending promising young members to America for higher education so that they could come back to Southern Rhodesia and take over leadership of the church. Muzorewa Dodge 1986: 138) writes that he and many others would never forget that it was Bishop Dodge who had the vision and determination to crash through the barrier to higher education for Zimbabweans. Not only did the Bishop send young church members to be trained for church positions, but he encouraged those selected to train for teaching, journalism, law and medicine and also for Christian ministry (Dodge 1986: 138). In light of such encouragement, one sees that Dodge's views on racial justice were increasingly radical. His aim was to offer young Africans opportunities that were given to their White Rhodesian counterparts which they could not get in Rhodesia. Prior to this radical move of educating Africans by Bishop Dodge, instead of teaching the African students to think independently and to develop fully as human beings, much of the curriculum, especially the religious elements, trained the Africans to be obedient to their white masters (Maenzanise 2008:75). In refusing to join the bandwagon of other missionaries who seemed to flow with the expectations 
of the Rhodesian government, Dodge resisted gullibility to the status quo.

Dodge's actions were a radical break from the usual pattern of the missionaries. Muzorewa (in Dodge 1986: viii) argues that Dodge's prophetic ministry was a challenge for those who may doubt Christ's role in social change. His sermons, teachings, conversations and actions manifested his radical ideas. As a spokesman of the American Methodist Church, he was committed to fighting against racial oppression by the white minority in Southern Rhodesia. He voiced the concerns of the African people in Rhodesia at the very time the political parties were banned and their leaders silenced in detention. He preached a gospel of political and spiritual freedom and played a leading role in the denunciation of the proposed Unilateral Declaration of Independence (UDI) of Southern Rhodesia. He also criticised the Smith government's practice of detaining people without trial (Thomas 1985:121; Maenzanise 2008: 78). Dodge also published a book which was a critique of missionary work in Africa entitled The Unpopular Missionary which was not well received by the Rhodesian government. This, together with his outspoken opposition of the proposed UDI and his educational policies, caused his deportation (Peaden 1979: 196; Thomas 1985: 121; Maenzanise 2008: 78). The deportation of Dodge shows that the Rhodesian government was not in support of his ideologies, even though they did not give him a reason why they deported him. Dodge was given no reason for his deportation, but he believed that sending young people for higher education was wrongly interpreted by the government who claimed that they had gone for training in subversion (Peaden 1979: 196). In refusing to be gullible to the government, Dodge was deported, and those missionaries who were not open critice of the government remained.

More evidence of Dodge not being gullible is in the fact that he had good relations with the African nationalists and encouraged many of them to be educated and participate in politics and other administrative tasks. His message was very relevant to the context of the times he ministered, much to the chagrin of the colonial government. He was a preacher and a writer and published many articles that addressed the situation in Southern Rhodesia. In his book, The unpopular missionary, he challenged the agenda of missionary work during that time. He claimed that the major blind spot of the total missionary program in Africa may well have been the failure of white church leaders to train nationals for administrative responsibility. He observed that some colonial governments had shown an interest in educating the masses in 


\section{Margaret Chinyadza}

central Africa, but none had set about training Africans realistically for administrative responsibility under a democracy (Dodge 1986: 153). To support his message, he had the tendency of appointing Africans to positions formerly meant just for whites. For example, he appointed Matthew Wakatama as the first Black principal of the Old Umtali Teacher Training College. This did not meet with the approval of the Department of Education in Rhodesia. He also promoted Africans at church administrative level and was questioned by other missionaries why he was undermining their authority in terms of the discipline of blacks.

Bishop Dodge also published a substantial number of articles. He would address different social phenomena in which the church was directly involved. Some of these included, 'The Church and Freedom', 'The Church and Society' and 'The Church and Politics'. The forewords to his books were always done by the educated African elite. In one foreword on church and freedom, Walter Joseph Kamba accuses the church of having fostered the opposition of African nationalist parties because of its failure to condemn and in fact often condoning social and political discrimination. He accused the church of having lost the respect and trust of the educated African due its traditional silence on matters other than sinning. Kamba's accusation of the church speaks of a church which was gullible to the system. In this article however, in contrast to the traditional silence of the church, Dodge argues that the church believed that all people should have as much freedom as possible. He supported freedom, which he claimed led to creativity. He believed that freedom from domination in politics, education or religion brought out the best in an individual. The church believes in selfdetermination, so people should be free to choose the political side they wanted. He was against intimidation which, he argued, negated the right of the individual to make his own choice.

Ndabaningi Sithole wrote a foreword to Dodge's Church and society, in which he states that politics is a filthy game, but then Christians should participate in it to purify it. He argues that it is not right that they should have nothing to do with it. Sithole's foreword shows that Dodge was in the right direction in condemning the oppression the blacks were facing at the hands of the colonial government. In the article on church and society Dodge declares

${ }^{1}$ Please note that the articles published by Dodge were undated and so they will be cited without the dates. 
that life is a totality and Christian participation in all phases of life, politics included, is a desirable thing. He asserts that all aspects of man's life are related and so man's desire for political freedom is as much a part of him as his desire for economic advancement, spiritual certainty or intellectual maturity. He argues that the Christian should participate in all phases of life, as the politics of the nation directly affects the life of the church.

Dodge's writings show that he was not easily manipulated into believing that the situation in Rhodesia was normal. He was not naïve or credulous, nether was he uncritical of the situation in Southern Rhodesia. He was critical of the system, spoke against it and acted to bring about the change he advocated. He was a man who set an example of what is to be done, much to the chagrin of the Rhodesian government.

\section{Political Situation in the Years 2000 - 2008}

According to Alden (2002), Zimbabwe faced multiple crises which were a) a crisis of legitimacy as its postcolonial consensus crumbled; b) a crisis of expectation stemming from the failure of its economy and polity; and c) a crisis of confidence in the impartiality of the institutions of the state. Since the government's defeat in the February 2000 constitutional referendum, ZANU PF largely succeeded in re-imposing its control through a holistic strategy of repression (Togarasei 2013: 98). The crisis in Zimbabwe during this period was such that the security sector of the country was immune from the law and it occupied prominent positions in intelligence, provincial administration and even electoral administration (Kibble 2004). There was a state-driven violent land occupation which ,according to Pius Ncube, was not an attempt to help the landless, but a move to hold on to power (Kibble 2004; La Guardia 2004). Media freedom was shattered by the imposition of the Access to Information and Protection of Privacy Act (AIPPA) seen in the constant harassment of independent media and the shutting down of the Daily News, newspaper. The judiciary was restructured in such a way that it was in complete compliance with the government's bidding. With the judiciary being a puppet to the ruling party, there was destabilisation of trade unions, NGOs and other civic organisations. To add to that, there was torture and intimidation of individuals with a crackdown on the human rights sector. The religious leadership was not spared either, with the co-option or denigration of religious leadership, depending on which side one spoke from. Violence was also used as 
an election strategy, with the bodies responsible for electoral administration firmly under government control, including the use of military person 1 .

The church's position during this trying time in Zimbabwe's history was varied. Chitando (2013) observes that the church-state relations in Zimbabwe after independence were almost similar to colonial times in that there are some church leaders who are close to those who wield political power. This can be interpreted as being gullible to the status quo. These included leading church figures such as Archbishop Patrick Chakaipa, who interacted closely with Mugabe (Auret 2009: 137-138). Then there were those who were not gullible and were strong critics of the government such as Archbishop Pius Ncube.

The church in Zimbabwe has always been part and parcel of the struggles facing the nation. Traditional bodies that dealt with the crisis are the Zimbabwe Catholic Bishop's Conference (ZCBC), Evangelical Fellowship of Zimbabwe (EFZ) and the Zimbabwe Council of Churches (ZCC). New bodies formed due to the crisis were Churches in Manicaland, Christians Together for Justice and Peace, Churches in Bulawayo, Christian Alliance, and the Zimbabwe National Pastors' Conference (Togarasei 2013: 100). With these criticisms, Mugabe and his cronies started extending their hand to other churches that were more gullible, especially the African Independent Churches and some Pentecostal churches. These began to be given the responsibility to pray at political gatherings, a responsibility that had previously been reserved for the Catholic Church and other mainline churches.

\section{The Gullible Ones}

Some Pentecostal leaders during the crisis period were not entirely critical of the government of the day. Andrew Wutawunashe of the Family of God declared that the results of the presidential elections of 2002 were the will of God. This he stated despite the fact that they were widely regarded as fraudulent (Togarasei 2008: 75-88). Wutawunashe soon became a darling religious minister of the state as he was invited to state functions and enjoyed positive state media coverage. His church even established the Faith for the Nation Campaign desk. This was a platform through which the church addressed political issues (Togarasei 2006: 215-225). Wutaunashe was not alone in showering the government of the day with praises. The Celebration Church founder and senior pastor Tom Deuschle in 2004 declared that then 
President Mugabe had been blessed by God and that he was God's gift to the nation of Zimbabwe because God establishes leaders (Togarasei 2013: 102). The Celebration Church even presented the president with a monetary gift, a portrait and Bible storybooks for his children. Another controversial Pentecostal minister who responded to the crisis was Obadiah Msindo of the Destiny of Africa Ministries. Like the government of the day, Msindo viewed the crisis unfolding in Zimbabwe as a creation by the Western world to depose President Mugabe. He supported the government openly through running building projects, conducting economic empowerment workshops and spreading government propaganda on radio and television (Togarasei 2013: 103). He also openly campaigned for the ruling ZANU PF. In spite of the above who supported the government of the day, one lone voice stood out against the government, namely that of Archbishop Pius Ncube.

\section{In Defiance of the Status Quo: Pius Ncube}

During the crisis period in Zimbabwe between 2000 and 2007, Pius Ncube was the Roman Catholic archbishop of Bulawayo and very vocal about the nature of government which was generally oppressive to the majority of Zimbabwean people. His became the loudest voice of defiance against the injustices of Robert Mugabe. Chitando, Taringa and Mapuranga (2014) report, 'He was bold enough to call on people to rise up against Mugabe's rule and he even declared his readiness to go in front of blazing guns'. He spoke at a time Zimbabwe's political rivals were harassed, imprisoned and tortured; independent newspapers closed down and a whole population being cowed by economic collapse and food shortages (La Guardia 2004). Pius Ncube spoke vehemently against the Gukurahundi in which researchers say between 2000 and 8000 people were killed, at least 10000 arrested and 7000 beaten or tortured (La Guardia 2004). Sibanda (in Chitando et al. 2014) states that Ncube demanded that Mugabe disclose the massacre of thousands of civilians in Matabeleland and the Midlands provinces by troops who crushed a purported army insurgency against his rule soon after independence. Pius Ncube spoke against the injustices of the land reform programme. He claimed that only $2 \%$ of the land was distributed to farmers and the rest was given to ministers and Mugabe's friends. For him to be quiet in the face of such gross human rights violations was a disservice to the people of Zimbabwe and disloyal to Christ. 
Pius Ncube proved that he was not gullible to the governmental system of the day as reported by Alex Perry (2007) of Time Magazine. He was reported as one of President Robert Mugabe's most outspoken critics who in 2007 offered to lead a street campaign to oust him. He accused Mugabe of being extremely power conscious and being obsessed with anything that disturbed his power base. He went on to accuse Mugabe of fuelling the economic collapse of the nation through the land reform which according to him was done to spite the white farmers who supported Morgan Tsvangirai. Ncube claimed that inflation was at $4000 \%$, prices doubled every two days, with people leaving the country daily. Being a cleric he bemoaned the government's lack of moral values, as the country suffered, with children out of school and the officials continuing with their corrupt and cruel agendas. Ncube observed that the government did not seem to care for the health of its people, leaving the care of most Zimbabweans in the hands of the World Food Programme. He also exposed the uncaring nature of some government officials, an example being Didymus Mutasa. He quoted Mutasa, then Minister of State Security as saying, 'We would be better off with only six million people, with our own (supporters). We don't want all these extra people'. Such intolerance was deplorable to Ncube.

Ncube also published a damning report on the inhuman Operation Murambatsvina of 2005. According to the report, up to 1.5 million people were made homeless. More than 300000 homes were destroyed, more than 46000 people were arrested and over 4 million people were left starving (Ncube, P., Bate, R., and Tren, R.: 2005). In defiance of the system, Ncube had the guts to criticise the operation and to write a report exposing the evil orchestrated on the Zimbabwean populace. In the summary of the report, he commented that President Mugabe remained president of Zimbabwe only through corruption of the democratic process and the legal system and through suppression of the opposition. Mugabe was accused of desperately trying to maintain power and control by employing tactics used against guerrilla fighters in Rhodesia in the 1970s. In light of all this, Ncube appealed to the international community to act against Mugabe. In being a voice for the voiceless, Ncube proved that he was not gullible; however his critical nature had consequences.

Ncube's utterances were not received well by Mugabe's regime. He and other church leaders were accused of speaking falsely against the governance of the country and Robert Mugabe urged the people of Zimbabwe 
not to listen to them. In the Herald of 5 May 2007, Mugabe is quoted as saying,

Once the bishops turn political, we regard them as no longer spiritual and our relations with them would be conducted as if we are dealing with political entities and this is quite a dangerous path they have chosen for themselves.

Because of his speaking out against the government, his telephones were tapped, government agents monitored his every sermon and he was told that he was on the police death list. To add to that, the state-controlled press accused him of raping nuns, fathering bastard children and indulging in homosexual acts with prisoners (La Guardia 2004). Nathan Shamuyarira (in La Guardia 2004), one of Mugabe's ministers, accused him of being 'a propagandist who works for the racist imperialist government to undermine the Zimbabwean government'. Due to Ncube's utterances, the church was labelled as a church that supported white supremacy. As a result of this, Mugabe turned to the white garment churches for support which he readily got. Ncube was silenced by his being accused of infidelity and had to resign from his post of Archbishop in 2007.

\section{Conclusion}

The article has shown us some important aspects. Firstly, the periods in which the two clergy men operated were both oppressive and they stood as lone voices to criticise the status quo, thus refusing to be gullible. Secondly, they practised prophetic political theology, which was a refusal to be gullible to the policies of the government of the day. Thirdly, their refusal to be gullible had a detrimental effect on them, as they were both silenced by the governments of their time. Dodge was deported for his refusal to align himself with government policies that encouraged the oppression of the black majority. The fact that some missionaries did not support Dodge's stance shows that there were some who were in support of the government's stance, or maybe they were afraid to raise their voices. In Ncube's case he refused to be silent in the face of the suffering of the masses. As in Dodge's case, there were also some ministers who were in support of the status quo. This was doing injustice to the liberating scripture of Luke 4:18. The support these 
ministers gave to the government shows gullibility to a system that went against biblical principles. The article has also shown that political theology is safest when done under the umbrella of an organisation. Under an organisation, the government cannot victimise individuals like it did in the case of Dodge and Ncube.

\section{References}

Alden, C. 2002. South Africa's Quiet Diplomacy and the Crisis in Zimbabwe.

Cardenos de Estudoes Africanos 2, Janeiro/ Julho. Available at: https://journalsopenedition.org (Accessed on 19 September 2019.)

Auret, M. 2009. From Liberator to Dictator: An Insider's Account of Robert Mugabe's Descent into Tyranny. South Africa: David Phillip.

Chitando, E. (ed.). 2013. Prayers and Players: Religion and Politics in Zimbabwe. Harare: Sapes Books.

Chitando, E., N.T. Taringa \& T.P. Mapuranga 2014. Zimbabwean Theology and Religious Studies during the Crisis Years (2000 - 2008): A Preliminary Study. Studia Historiae Ecclesiasticae 40,1:173 - 189. Available at: http://www.scielo.org.za/scielo.php (Accessed on 19 September 2019.)

Daneel, M.L. 1971. Old and New in Southern Shona Independent Churches:

Volume 1: Background and Rise of the Major Movements. The Hague: Mouton.

Dodge, R.E. 1986. The Revolutionary Bishop who Saw God at Work in Africa. California. William Carey Library.

Goepp, P.H. \& M.W. Kay 1984. Merriam-Webster's Dictionary of

Synonyms: A Dictionary of Discriminated Synonyms with Antonyms and Analogous and Contrasted Words. Springfield, MA: Merriam-Webster.

Greenspan, S. 2009. Annals of Gullibility: Why we get Duped and How to Avoid it. Westport, CT, US: Praeger Publishers/ Greenwood Publishing Group.

Gunda, M.R. \& A.K. Mtetwa 2013. The Bible as a Political Resource in Zimbabwe: The Subtleness of Biblical Teachings in Zimbabwean Politics. In Chitando, E. (ed.): Multiplying in the Spirit: African Initiated Churches in Zimbabwe. Bamberg: University of Bamberg Press.

Jewell, E. (ed). 2006. Pocket Oxford Dictionary \& Thesaurus. $2^{\text {nd }}$ American Edition. New York: Oxford University Press US. 
Kaiso, G. 2010. The Church and Good Governance. Available at:

https://religionunplugged.com/news/index.php

(Accessed on 20 September 2019.)

Kee, A. 1978. The Scope of Political Theology. London: SCM Press.

Kibble, S. 2004. Zimbabwe: The Government wants the People to Give up Hoping. (Archbishop Pius Ncube, Bulawayo). Review of African Political Economy 31, 100: 364 - 372. Available at:

http://www.jstor.org/stable/ 4006900 (Accessed on 21 September 2019.)

La Guardia, A. 2004. 'I'm not going to be bullied by Mugabe'. The Telegraph. Available at: https://telegraph.co.uk

(Accessed on 19/09/2019).

Maboyi, A. 2015. Role of Religion in Colonialism. Available at: https://www.chronicle.co.zw (Accessed on 21 September 2019.)

Maenzanise, B. 2008. The Church and Zimbabwe's Liberation Struggle. Methodist History 46:2. Available at www.archives,gcah.org (Accessed on 20 August 2019.)

Metz, J.-B. 2013. Two-fold Political Theology. In Schüssler-Fiorenza, F., K. Tanner \& M. Welker (eds.): Political Theology: Contemporary Challenges and Future Directions. Louisville: Westminster/ John Knox Press.

Moltmann, J. 2013. Political Theology in Ecumenical Contexts. In SchüsslerFiorenza, F., K. Tanner \& M. Welker (eds.): Political Theology: Contemporary Challenges and Future Directions. Louisville: Westminster/ John Knox Press.

Muchena, D.T. 2004. The Church and Reconciliation: A Mission Impossible?

In Raftopoulos, B. \& T. Savage (eds.): Zimbabwe: Injustice and Political Reconciliation. Harare: Weaver Press.

Ncube, P., R. Bate \& R. Tren 2005. State in Fear: Zimbabwe's Tragedy is Africa's Shame. A Report on Operation Murambatsvina - 'Operation Drive out the Filth' - and its Implications. Available at: www.archive.kubatana.net $>$ html $>$ archive $>$ demgg

(Accessed on 25 august 2019.)

New International Version. Holy Bible. 1984. Luke 4 Verse 18. England: International Bible Society.

Nkomo, J. 1984. The Story of my Life. Zimbabwe: Pacprint.

Okunoye, J.O. 2012. The Role of the Church towards Achieving Good Governance in Nigeria. In Ayantayo, J.K., O.A. Dada \& H.A. Labeodan 
(eds.): Religion and Governance in Nigeria. Available at: www.slideshare.net (Accessed on 28 August 2019.)

Peaden, W.R. 1979. Aspects of the Church and its Political Involvement in Southern Rhodesia, 1959-1972. Available at:

http://digital.lib.msu.edu/projects/africanjournals/

(Accessed on 29 August 2019.)

Perry, A. 2007. Zimbabwe's Outspoken Archbishop. Available at: https://www.content.time.com (Accessed on 28 August 2019.)

Schmitt, C. 2012. Political Theology. In Cavanaugh, W.T., J.W. Bailey \& C.

Hovey (eds.): An Eerdmans Reader in Contemporary Political Theology.

Grand Rapids, MI: Eerdmans.

Schüssler-Fiorenza, F. 2013. Critical Feminist Theology of Liberation: A Decolonizing Political Theology. In Schüssler-Fiorenza, F., F.K. Tanner \& M. Welker (eds): Political Theology: Contemporary Challenges and Future Directions. Louisville CY. Westminster: John Knox Press.

Sithole, N. 1968. African Nationalism. London: Oxford University Press.

Thomas, N.E. 1985. Church and State in Zimbabwe. Journal of Church and

State 27, 1, Winter: 113 - 133. Available at:

https://doi.org/10.1093/jcs/27.1.113 (Accessed 25/08/2019)

Togarasei, L. 2008. Jerusalem and Antioch: Inter-state, Intra-church Politics in the Family of God Church in Botswana. PULA: Botswana Journal of African Studies 22,1: $75-88$.

Togarasei, L. 2013. Pentecostal Churches and Politics in Zimbabwe's Turbulent Years (2000 - 2008). In Chitando, E. (ed.): Prayers and Players: Religion and Politics in Zimbabwe. Harare: SAPES BOOKS.

Van Wyk, T. 2015. Political Theology as Critical Theology. HTS Teologiese Studies/ Theological Studies 71,3: Art. \#3026, 8 pages. Available at: http://dx.doi.org/10.4102/hts (Accessed on 28 August 2019.)

Yamagishi, T., M. Kikuchi \& M. Kosugi 1999. Trust, Gullibility, and Social Intelligence. Asian Journal of Social Psychology 2,1. Available at: https://doi.org.10.1111/1467-839X.00030 (Accessed on 28 August 2019.)

Maragret Chinyadza Church History Africa University Mutare chinyadzam@africau.edu 